\section{Variable-rate Spray Technology Optimizes Pesticide Application by Adjusting for Seasonal Shifts in Deciduous Perennial Crops}

\author{
Lloyd L. Nackley ${ }^{1}$, Brent Warneke ${ }^{2}$, Lauren Fessler ${ }^{3}$, \\ Jay W. Pscheidt ${ }^{2}$, David Lockwood ${ }^{3}$, Wesley C. Wright ${ }^{4}$, \\ Xiaocun Sun ${ }^{5}$, and Amy Fulcher ${ }^{3}$
}

ADDITIONAL INDEX WORDs. intelligent sprayer, orchard, pesticide drift, phenology, precision agriculture, vineyard

Summary. To optimize pesticide applications to the canopies of deciduous perennial crops, spray volume should be adjusted throughout the year to match the changes in canopy volume and density. Machine-vision, computer-controlled, variable-rate sprayers are now commercially available and claim to provide adequate coverage with decreased spray volumes compared with constant-rate sprayers. However, there is little research comparing variable- and constant-rate spray applications as crop characteristics change throughout a growing season. This study evaluated spray volume, spray quality (e.g., coverage and deposit density), and off-target spray losses of variable- and constant-rate sprayers across multiple phenophases in an apple (Malus domestica) orchard and a grape (Vitis vinifera) vineyard. The variable-rate sprayer mode applied $67 \%$ to $74 \%$ less volume in the orchard and $61 \%$ to $80 \%$ less volume in the vineyard. Spray coverage (percent), measured by water-sensitive cards (WSC), was consistently greater in the constant-rate mode compared with the variable-rate mode, but in many cases, excessive coverage (i.e., over-spray) was recorded. The variable-rate sprayer reduced off-target losses, measured by WSC coverage, up to $40 \%$ in the orchard and up to $33 \%$ in the vineyard. Spray application deposit densities (droplets per square centimeter) on target canopies were typically greater in variable-rate mode. However, the deposit densities were confounded in over-spray conditions because droplets coalesced on the WSC resulting in artificially low values (i.e., few, very large droplets). Spray efficiencies were most improved early in the growing season, when canopy density was lowest, demonstrating the importance of tailoring spray volume to plant canopy characteristics.

$\mathrm{P}$ esticide spray applications must adapt to seasonal plant growth to minimize off-target losses of agricultural chemicals and reduce environmental and human health hazards. The canopies of perennial crops change over the season as buds burst, branches develop, fruit form, and crops are harvested. Each phenophase has variable intra and interseasonal canopy development that requires variable-rate pesticide applications for maximal application efficiency (Chen et al., 2013a; Gil and Escolà, 2009; Llorens et al., 2010). In addition to natural growth changes, the structure and density of a crop canopy are often highly altered by horticultural practices. For example, producers commonly reduce the canopy density to improve light and air infiltration, promote fruit ripening, and reduce disease pressure (Austin et al., 2011). While tree row volume is an established method for adjusting the volume of pesticide to match plant canopy growth (Gil and Escolà, 2009; Rüegg and Viret, 1999; da Silva Scapin et al., 2015), in practice, pesticide volumes are usually based on the two-dimensional field area (e.g., gallons per acre) and predicated on historical use patterns, as opposed to being modified based on three-dimensional changes in the plant canopy. A spray rate that does not adapt to match the canopy volume and density increases the likelihood of overspraying when the canopy is sparsely developed and underspraying when the canopy is at its fullest.

Most specialty crop producers rely on frequent applications of pesticides due to intense pressure from pests and diseases and to meet the stringent aesthetic requirements for marketable fruits and vegetables. In apple (Malus domestica) orchard and grape (Vitis vinifera) vineyards, up to weekly pesticide applications are applied during the growing season (Chen et al., 2020; Thiessen et al., 2017). Costs associated with pesticide applications (e.g., chemicals, equipment, labor) can account for $30 \%$ or more of the annual operating costs for an orchard (Bechtel et al., 1995) or a vineyard (Sambucci et al., 2014). Airassisted sprayers are used throughout the world to apply insecticides and fungicides to orchards, vineyards, and other specialty crop production systems (Warneke et al., 2020). Air-assisted sprayers deliver pesticides by atomizing droplets of an aqueous chemical mixture into a high-velocity air stream. The blast of air is designed to displace the air in the crop canopy with a stream of pesticide droplets. Air-assisted sprayers were originally designed to apply pesticides to large fruit trees, often $20 \mathrm{ft}$ or more in height at maturity, but modern fruit orchards often produce on trees 6 to $12 \mathrm{ft}$ tall (Fox et al., 2008; Warneke et al., 2020). Therefore, standard airassisted sprayers are often overpowered for modern crops and eject droplets above and beyond the canopy, whereby some droplets escape into the atmosphere (Grella et al., 2019). Research has demonstrated that when air-assisted sprayers apply a constant spray rate without considering the plant size, shape, or pest location that

\begin{tabular}{llll}
\hline $\begin{array}{l}\text { Units } \\
\text { To convert U.S. to SI, } \\
\text { multiply by }\end{array}$ & U.S. unit & SI unit & $\begin{array}{l}\text { To convert SI to U.S., } \\
\text { multiply by }\end{array}$ \\
\hline 1.0444 & $\mathrm{fl} \mathrm{oz} / \mathrm{ft}^{3}$ & $\mathrm{~L} \cdot \mathrm{m}^{-3}$ & 0.9575 \\
0.3048 & $\mathrm{ft}$ & $\mathrm{m}$ & 3.2808 \\
0.0283 & $\mathrm{ft}^{3}$ & $\mathrm{~m}^{3}$ & 35.3147 \\
3.7854 & gal & $\mathrm{L}$ & 0.2642 \\
9.3540 & gal/acre & $\mathrm{L} \cdot \mathrm{ha}^{-1}$ & 0.1069 \\
2.54 & inch(es) & $\mathrm{cm}^{2}$ & 0.3937 \\
6.4516 & inch & $\mathrm{cm}^{2}$ & 0.1550 \\
0.4470 & $\mathrm{mph}$ & $\mathrm{m} \cdot \mathrm{s}^{-1}$ & 2.2369 \\
6.8948 & $\mathrm{psi}$ & $\mathrm{kPa}$ & 0.1450 \\
$\left({ }^{\circ} \mathrm{F}-32\right) \div 1.8$ & ${ }^{\circ} \mathrm{F}$ & ${ }^{\circ} \mathrm{C}$ & $\left({ }^{\circ} \mathrm{C} \times 1.8\right)+32$
\end{tabular}


plants are often undersprayed or oversprayed (Fessler et al., 2020).

Optimizing spray applications is necessary to address increasing pesticide expenses, limited labor availability, stricter regulations, and increased public awareness of pesticide use (Giles et al., 2011). A sensor-guided sprayer can apply a variable-rate spray that adapts to the changing canopy volume and density thereby reducing waste and off-target deposition compared with standard constant-rate sprayers (Chen et al., 2013b; Giles et al., 2011; Tona et al., 2018). A previous comparison between a constantrate sprayer and a laser-guided, variable-rate sprayer at an apple orchard in Ohio demonstrated reduced offtarget losses from $70 \%$ to $90 \%$ and reduced the spray volume by $50 \%$ to $70 \%$ (Chen et al., 2013b). However, research comparing standard air-blast sprayers and laser-guided, variablerate sprayers has not been conducted in many other crop systems in many other locations, which is important because orchards and vineyards are known for their variability because many are located on uneven terrain, managed by hand labor, and owned

Received for publication 7 Jan. 2021. Accepted for publication 21 Apr. 2021

Published online 8 June 2021.

${ }^{1}$ Horticulture Department, Oregon State University, North Willamette Research and Extension Center, Aurora, OR 97002

${ }^{2}$ Botany and Plant Pathology Department, Oregon State University, Corvallis, OR 97333

${ }^{3}$ Department of Plant Sciences, University of Tennessee, Knoxville, TN 37996

${ }^{4}$ Department of Biosystems Engineering and Soil Science, University of Tennessee, Knoxville, TN 37996

${ }^{5}$ Office of Information Technology, University of Tennessee, Knoxville, TN 37996

We thank Trystan Bordeau, Mark Burnett, Heping Zhu, Adam Clark, Luc Nadaud, Grace Pietsch, and Whitney Yeary for their assistance and David Butler and Brian Hill for their careful review of an earlier version of this manuscript. Oren Wooden's Apple House, Pikeville, TN, generously provided facilities, labor, and resources that made this research possible.

This research was supported by the Advancement of Pesticide Spray Applications in Specialty Crop Production with Intelligent-Decision Technologies (U.S. Department of Agriculture National Institute of Food and Agriculture Specialty Crops Research Initiative Grant No. 2015-51181-24253) and Tennessee Hatch 1009630.

A.F. is the corresponding author. E-mail address: afulcher@utk.edu.

This is an open access article distributed under the CC BY-NC-ND license (https://creativecommons. org/licenses/by-nc-nd/4.0/).

https://doi.org/10.21273/HORTTECH04794-21 by small, private companies. Therefore, the objective of this study was to evaluate the effect of variable- and constant-rate spray applications and phenological stage on spray volume, coverage, and deposit density in two perennial specialty crop systems: an apple orchard and a grape vineyard.

\section{Materials and methods}

Field tests were conducted at an apple orchard in Tennessee and a grape vineyard in Oregon. The orchard experiment was carried out at a commercial apple orchard in Pikeville, TN (lat. $25^{\circ} 32^{\prime} 53.8584^{\prime \prime} \mathrm{N}$, long. $\left.85^{\circ} 9^{\prime} 10.1304^{\prime \prime} \mathrm{W}\right)$ on 'Red Rome' apple trees on Malling 26 (M26) dwarfing rootstock planted in 2011 with 6 $\mathrm{ft}$ between trees within the row and $23 \mathrm{ft}$ between rows (Fig. 1). Trees were trained to a central leader system. They were primarily pruned in the dormant season with light pruning in the summer. Chemical thinners were used as the initial and primary practice to reduce crop load beginning with petal fall. Hand thinning was used secondarily to break up fruit clusters and to refine the crop load through 1.5 inches fruit diameter. A weather station consisting of an anemometer (034A-L Wind Set; Met One, Grants Pass, OR) and an air temperature and relative humidity sensor (HMP60-10-PT; Vaisala Corp., Helsinki, Finland) was located within the orchard $\approx 120 \mathrm{~m}$ from the test plot (Table 1). Sensors were connected to a data logger (CR1000; Campbell Scientific, Logan, UT), and the station was powered by a solar panel.

The vineyard experiment was carried out at the Oregon State University Botany and Plant Pathology vineyard in Corvallis, OR (lat. $44^{\circ} 33^{\prime} 56.7^{\prime \prime} \mathrm{N}$, long. $123^{\circ} 14^{\prime} 42.7^{\prime \prime} \mathrm{W}$ ) on 'Pinot noir' planted in 1998 on Vitis rupestris $\times V$. riparia 101-14 rootstock with $7 \mathrm{ft}$ between vines within the row and $8 \mathrm{ft}$ between rows. Grapevines were trained to a guyot (vertical shoot position) system and pruned by 15 Mar. 2019. Shoot thinning by hand occurred from 1 to 10 May 2019, and sucker removal by hand was continuous throughout the season. Shoots were cut above the top training wire on 20 June 2019 and maintained at this height throughout the growing season.

A weather station consisting of a temperature probe (107, Campbell
Scientific), temperature and relative humidity probe (HC2S3; Rotronic, Hauppauge, NY), wind speed, and wind direction sensors $(014 \mathrm{~A}$ and $024 \mathrm{~A}$, Met One) was located $\approx 450 \mathrm{~m}$ northeast of the vineyard site. The weather station was powered by a solar panel.

Spray events were recorded as calendar dates with the corresponding stage on the Biologische Bundesantalt, Bundessortenamt, and Chemische $(\mathrm{BBCH})$ plant development scale (Meier, 2018).

\section{Sprayers}

Pesticides were applied with conventional air-assisted sprayers that were retrofitted with an intelligent spray system developed by the U.S. Department of Agriculture, which enables a variable-rate spray mode (Chen et al., 2012). The technology includes a high-speed scanning light detection and ranging (LiDAR) sensor (UTM-30LX; Hokuyo Automatic Co., Osaka, Japan), Doppler radar ground speed sensor (RVSIII radar velocity sensor; Dickey-John Corp., Auburn, IL), and embedded computer with a touchscreen interface. The LiDAR sensor scans the crop and uses plant presence and canopy density to determine the pesticide application volume, essentially automating the tree row volume calculation. The Doppler radar sensor independently measures the ground speed of the sprayer and times the release of spray onto the crop. LiDAR and ground speed data are processed (Liu and Zhu, 2016) and then relayed to an automatic flow control box that controls individual nozzles. A pulse width modulated solenoid valve (55295-112; TeeJet Technologies, Wheaton, IL) is fitted to each nozzle to operate each nozzle independently. The touch screen allows the spray operator to select the spray rate (fluid ounces of prepared spray solution per cubic foot of crop) and the switch box allows the operator to activate each side independently in intelligent, variable-rate mode, or manual, constant-rate mode.

OrCHARD. The orchard sprays were applied by a retrofitted air-assisted sprayer (1000 CS; AgTEC Superb Horticulture Co., Plymouth, IN) with a 1000-gal spray tank previously described by Fessler et al., (2020). Sprays were discharged through 14 nozzles, 7 


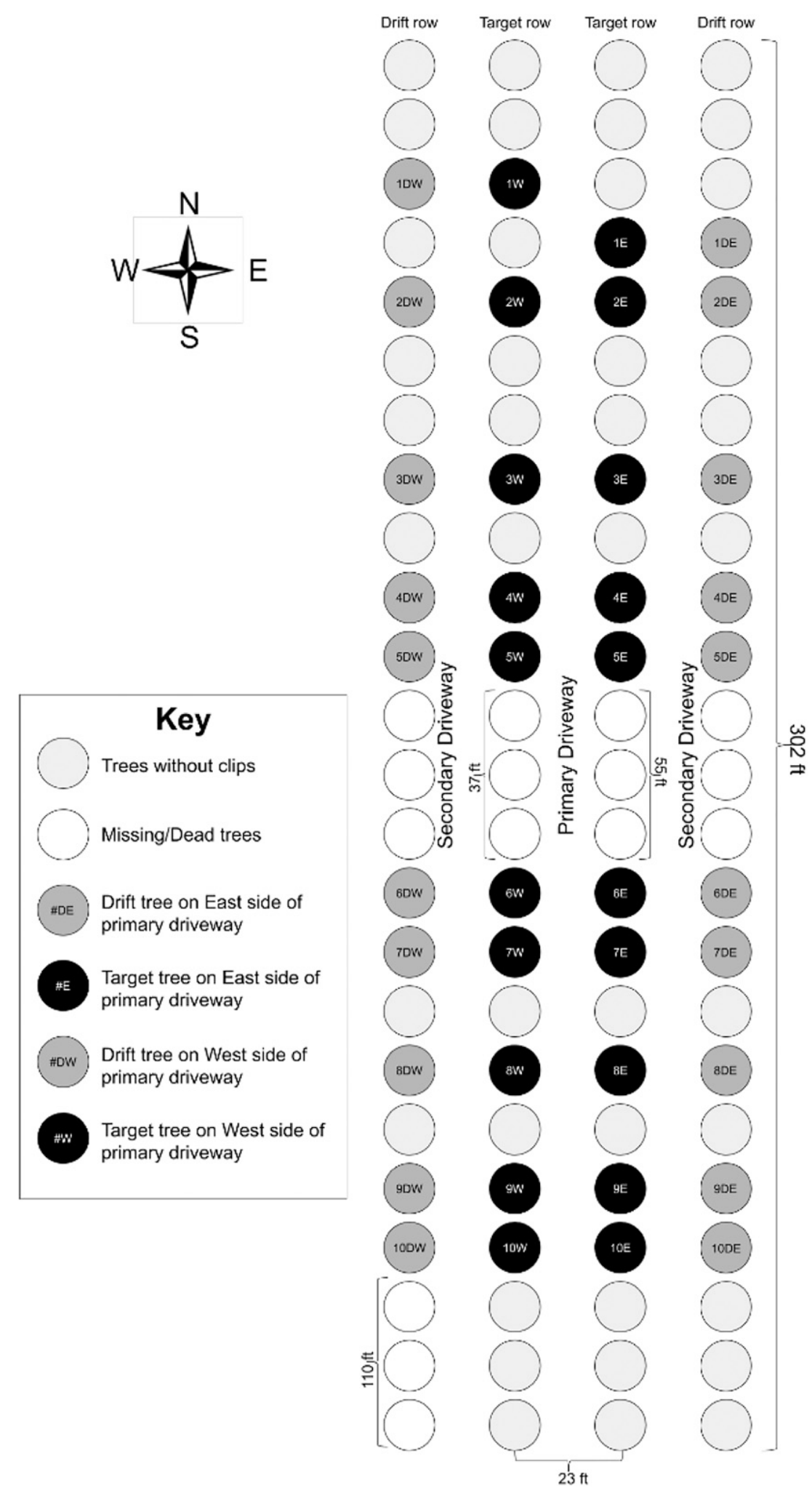

Fig. 1. Plot map of the commercial apple orchard in Pikeville, TN (lat. $25^{\circ} 32^{\prime} 53.8584^{\prime \prime} \mathrm{N}$, long. $\left.85^{\circ} 9^{\prime} 10.1304^{\prime \prime} \mathrm{W}\right)$. Target trees were selected from a pair of $302 \mathrm{ft}(92.0 \mathrm{~m})$ rows separated by a primary driveway. The rows of trees adjacent to each row of target trees were selected as drift-tree rows. Secondary driveways separated the target-tree rows and drift-tree rows. Ten pairs of trees were selected for monitoring spray characteristics in the target-tree rows using water-sensitive cards. nozzles on each side. Each nozzle had a specialized two-hole air-shear tip and was operated at 35 psi. The upper spray-head had two nozzles that were adjusted to discharge spray downward and a lower spray-head had five nozzles that discharged spray radially upwards. The variable-rate sprayer was operated at the default rate of $0.07 \mathrm{fl} \mathrm{oz} / \mathrm{ft}^{3}$ per crop canopy volume. The tractor was operated at 3.0 to $3.5 \mathrm{mph}$.

VINEYARD. The vineyard sprays were applied by a retrofitted radial fan air-assisted sprayer (Pak Blast; Rears Manufacturing, Coburg, OR) with a 50 -gal tank. The sprayer had 14 nozzles (D3 ceramic discs and DC25 core, TeeJet Technologies), 7 on each side. However, for this study the top and bottom nozzles were permanently closed since they would have been continuously aimed off-target and remained open in constant-rate mode. The nozzles were operated at 80 psi using only one side of the sprayer during the study because the experimental design sprayed alternate rows (Fig. 2). The variable-rate sprayer mode was set to $0.06 \mathrm{fl} \mathrm{oz} / \mathrm{ft}^{3}$ of crop volume. The sprayer was pulled and powered by a tractor driven at $2 \mathrm{mph}$.

\section{Spray quality monitoring}

OrChard. Target trees were selected from a pair of $302-\mathrm{ft}$ rows separated by a primary driveway. The rows of trees adjacent to each target tree row and distal to the primary driveway were selected as drift-tree rows. Secondary driveways separated the targettree rows and drift-tree rows. Ten pairs of trees were selected for monitoring spray characteristics in the target-tree rows. In each of the target trees, four pairs of $3 \times 2$-inch water-sensitive cards [WSC (TeeJet Technologies)] were attached, with clips, within the canopy. The target-tree WSC were positioned at 5.5 to $5.9 \mathrm{ft}$ high and were placed at equidistant locations within the canopy from east to west. Card positions were numbered 1 through 4 with position 1 being the closest to the primary driveway and position 4 being the closest to the secondary driveway (Fig. 1). The paired cards in positions 1 through 4 were clipped back-to-back so that one card faced the primary driveway $(\mathrm{P})$ and the other card faced the secondary driveway (S). Proximal card positions were the four closest cards facing the sprayer $(1 \mathrm{P}, 2 \mathrm{P}, 3 \mathrm{~S}$, 
Table 1. Weather conditions during spray applications. Data represent the average of the weather data points from the hour each application was made to each crop.

\begin{tabular}{|c|c|c|c|c|c|c|}
\hline Crop & Growth stage & Sprayer mode & $\begin{array}{l}\text { Wind speed } \\
\left(\mathrm{m} \cdot \mathrm{s}^{-1}\right)^{\mathrm{z}}\end{array}$ & $\begin{array}{c}\text { Wind } \\
\text { direction }\end{array}$ & $\begin{array}{l}\text { Air temp } \\
\left({ }^{\circ} \mathbf{C}\right)^{\mathrm{y}}\end{array}$ & $\begin{array}{c}\text { Relative } \\
\text { humidity (\%) }\end{array}$ \\
\hline \multirow[t]{4}{*}{ Orchard } & \multirow[t]{2}{*}{ Full bloom } & Variable rate & 0 & NW & 24.8 & 29.0 \\
\hline & & Constant rate & 0.02 & SSW & 21.2 & 44.1 \\
\hline & Fruit fall & Constant rate & 2.6 & S & 28.6 & 39.8 \\
\hline & Advanced ripening & Variable rate & 0.02 & S & 29.0 & 56.9 \\
\hline \multirow{2}{*}{ Vineyard } & Bloom & - & 3.0 & $\mathrm{NE}$ & 20.5 & 61.0 \\
\hline & Full canopy & - & 1.3 & SE & 25.0 & 48.0 \\
\hline
\end{tabular}

${ }^{\mathrm{z}}$ Wind speed at $2 \mathrm{~m}(6.56 \mathrm{ft})$ above the ground; $1 \mathrm{~m} \cdot \mathrm{s}^{-1}=2.2369 \mathrm{mph}$.

$\mathrm{y}\left(1.8 \times{ }^{\circ} \mathrm{C}+32\right)={ }^{\circ} \mathrm{F}$.

$4 S)$. Distal card positions were the four cards further away from the sprayer as it passed down the respective driveway (1S, 2S, 3P, 4P). A board with a single WSC attached face-up was placed on the ground at each target tree (position 5) to assess off-target ground spray. Ten trees in each drift-tree row were selected to correspond to each target tree. In each drift tree, a single WSC was placed in the same relative location of card position 1 facing the primary driveway (position 6).

Spray trials were conducted when trees reached full bloom [24 Apr. 2019 (BBCH 65-66)], fruit fall [29 May 2019 (BBCH 70-73)], and advanced ripening $[20$ Aug. 2019 (BBCH 83-85) (Fig. 3)]. On each spray day, the primary driveway was sprayed first.
After the first pass, the WSC in the drift trees (position 6) were allowed to dry and then collected. Next, the secondary driveways were each sprayed. After this second pass, the WSC in the target trees and on the ground were allowed to dry and then collected. Cards were collected in labeled envelopes and stored with desiccant. This spray procedure was first conducted in variablerate mode and then replicated in the same area in constant-rate mode. There were two areas of missing trees in this orchard block, and the nozzles were manually closed during the constantrate sprayer mode while the tractor was passing through these open stretches, as was the orchardist's normal practice. Spray volume data were collected at each growth stage using the embedded

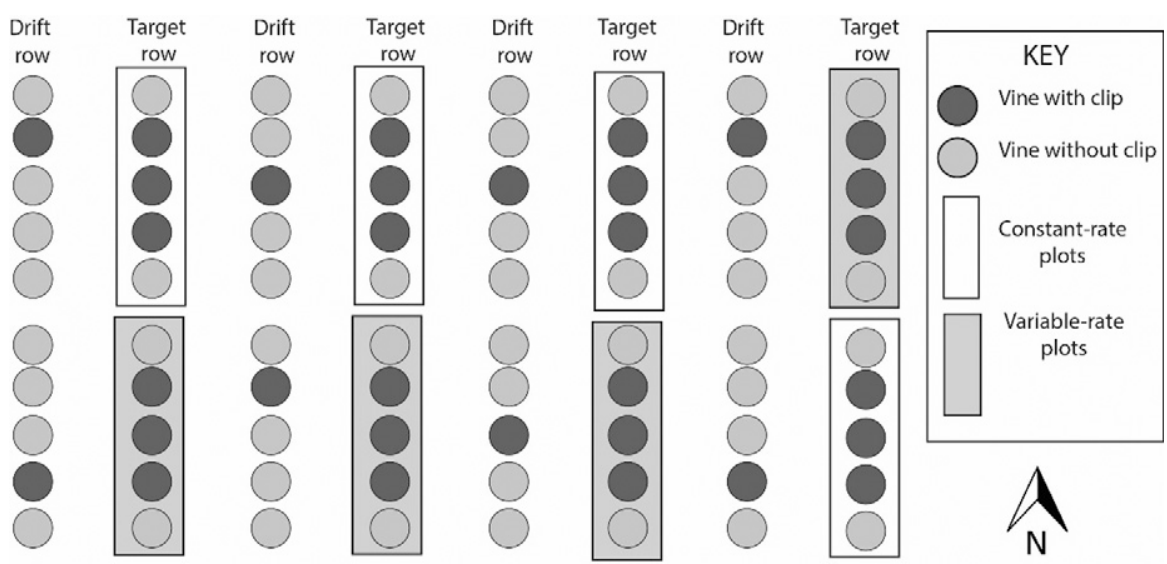

Fig. 2. Plot map of the grape vineyard at the Oregon State University Botany and Plant Pathology research farm in Corvallis, OR (lat. $44^{\circ} 33^{\prime} 56.7^{\prime \prime} \mathrm{N}$, long. $\left.123^{\circ} 14^{\prime} 42.7^{\prime \prime} \mathrm{W}\right)$ with $7 \mathrm{ft}(2.13 \mathrm{~m})$ between vines within the row and $8 \mathrm{ft}(2.43$ $\mathrm{m}$ ) between rows. Four rows of 'Pinot noir' in a multicultivar block were chosen for spraying. Between each row of target vines was a row of rootstock vines planted to minimize interrow interference. A plot within each of the four target rows was designated either for the variable-rate or the constant-rate spraying, creating four replicate plots of each sprayer mode. Groups of water-sensitive cards were placed in different positions within the vines to evaluate sprayer-mode application quality. computer that calculates sprayer output based on nozzle parameters previously entered into the user interface.

At each growth stage, canopy volume was recorded by measuring tree height, tree width across the row, and row length. Measurements from a line quantum sensor (LQS706; Apogee Instruments, Logan, UT) connected to a quantum meter (QMSS, Apogee Instruments) were taken as an indicator of canopy density. Within $24 \mathrm{~h}$ of each spray date, a leveled line quantum sensor was held in full sun and an initial measurement was taken. Immediately after this measurement, the sensor was held $\approx \mathrm{l} \mathrm{ft}$ from the base of a target tree, parallel to the row and centered on the trunk, and another measurement was taken. This process was repeated for each target tree. All measurements were taken from the west side of the trees where the shadow was being cast.

Vineyard. Four rows of 'Pinot noir' in a multicultivar block were chosen for spraying. Between each row of target vines was a buffer row of grapevines planted to minimize interrow interference. A plot within each of the four target rows was designated either for the variable-rate or the constantrate spraying, creating four replicate plots of each sprayer mode (Fig. 2). Groups of WSC were placed in different positions within the vines to evaluate sprayer-mode application quality. Two $1.5 \times 2$-inch WSC were placed back-to-back in the cluster zone of the grape canopy so that the water-sensitive side was facing out. The back-toback cards were clipped vertically so that one of the cards faced east and one faced west (positions CE and CW, respectively). Three of these cluster 

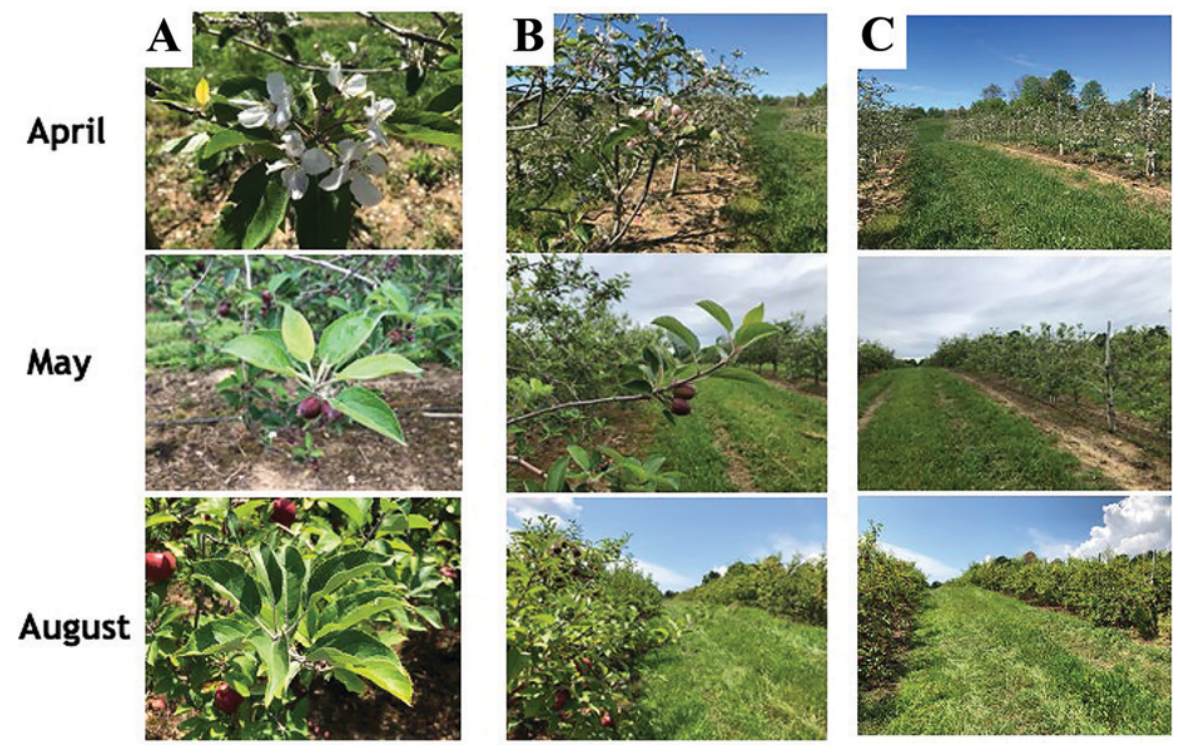

Fig. 3. Growth stages when the spray applications were made on apples based on the Biologische Bundesantalt, Bundessortenamt, and Chemische (BBCH) scale: (A) full bloom [24 Apr. 2019 (BBCH 65-66)], (B) fruit fall [29 May 2019 (BBCH 70-73)], and (C) advanced ripening [20 Aug. 2019 (BBCH 83-85)]. This orchard plot was located in Pikeville, TN (lat. $25^{\circ} 32^{\prime} 53.8584^{\prime \prime} \mathrm{N}$, long. $85^{\circ} 9^{\prime} 10.1304^{\prime \prime} \mathrm{W}$ ). zone card pairs were evenly distributed along each grape plot. At $\approx 5 \mathrm{ft}$ off the ground near the middle of the grape canopy, three WSC were stapled to the adaxial leaf surface $(\mathrm{AD})$, and another three WSC were stapled to the abaxial leaf surface $(\mathrm{AB})$. Additionally, two WSC were oriented vertically and placed $\approx 4 \mathrm{ft}$ off the ground in the adjacent buffer row (position D) to detect any nontarget spray.
Spray treatments were applied when the vines reached prebloom [30 May 2019 (BBCH 57)], full bloom [18 June 2019 (BBCH 65)], and midseason when plants had developed a full canopy [26 July 2019 (BBCH 79) (Fig. 4)]. During each spray event, the sprayer first traveled up one side of the target row, spraying plots, then down the other side of the row, spraying the same plots from the opposite side.
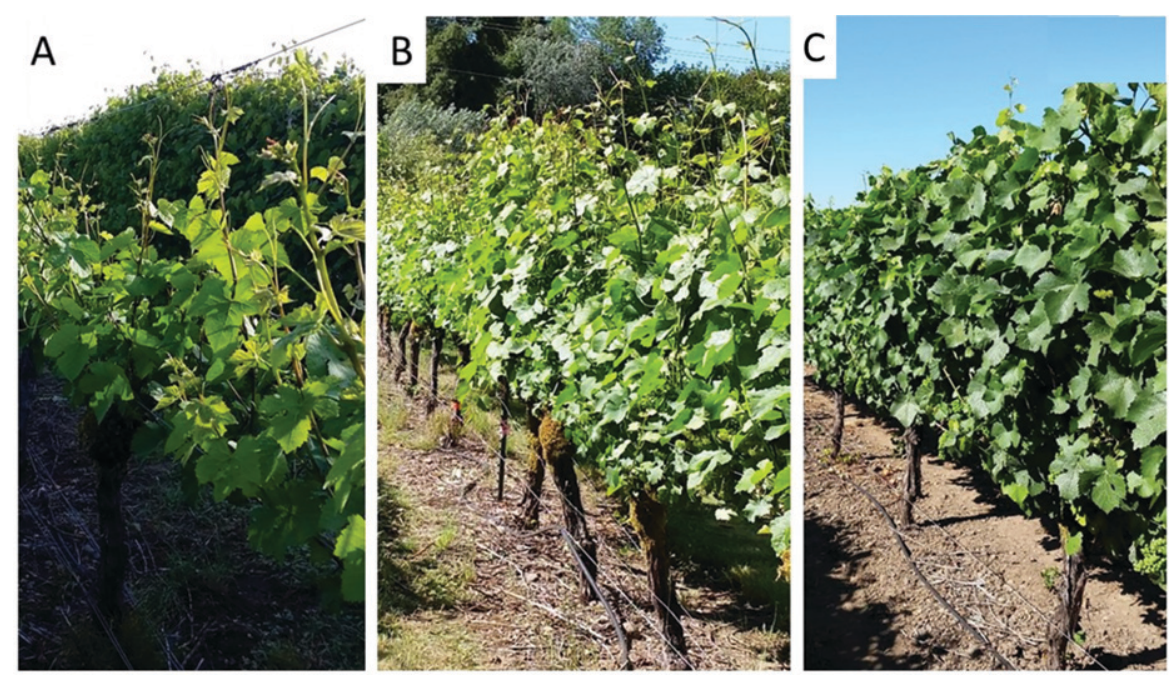

Fig. 4. Growth stages when the spray applications were made on grapes based on the Biologische Bundesantalt, Bundessortenamt, and Chemische (BBCH) scale: (A) prebloom [30 May 2019 (BBCH 57)], (B) full bloom [18 June 2019 (BBCH 65)], and (C) full canopy [26 July 2019 (BBCH 79)]. Experimental vineyard at located at Oregon State University in Corvallis (lat. $44^{\circ} 33^{\prime} 56.7^{\prime \prime} \mathrm{N}$, long. $\left.123^{\circ} 14^{\prime} 42.7^{\prime \prime} \mathrm{W}\right)$.
After $\approx 15$ to 30 min of drying time, the WSC were collected from all positions and placed into individual coin envelopes, then into zip-top plastic bags until analysis. Spray volume data were collected at each growth stage using the embedded computer. Canopy size measurements, (e.g., length and width) were collected manually, at each spray interval, using a measuring tape. Canopy density was measured automatically by the LiDAR sensor mounted on the sprayer, as part of the computer control spray calculations. The LiDAR density measurements are a unitless proportion (cubic foot per cubic foot).

\section{Statistical analyses}

The WSC were scanned at 600 dpi, saved as .jpg files, and analyzed using DepositScan software (Zhu et al., 2011). The DepositScan program was used to analyze the cards for spray coverage (percent) and deposit density (droplets per square centimeter). The effects of sprayer mode, card position, and growth stage on spray volume, coverage, and deposit density were analyzed using mixed model analysis for split-plot design with repeated measures, with the sprayer mode as the whole-plot effect, card position as the split-plot effect, and growth stage as the repeated factor. Crop measurements (vineyard: canopy density and volume, shoot length; orchard: canopy density and volume, tree height and width) and spray volume data were analyzed using repeated-measures analysis of variance, with sprayer mode as the between-subject effect while the plant growth stage was the within-subject effect. For all analyses, residuals were examined for model assumptions of normality and equal variance. Post hoc contrasts and multiple comparisons were performed with Tukey's adjustment. Statistical significance was identified at the level of 0.05. Analyses were conducted in SAS (version 9.4 TS1M4 for Windows 64x; SAS Institute, Cary, NC).

\section{Results \\ Environmental conditions}

Orchard. Wind speed ranged from 0 to $2.6 \mathrm{~m} \cdot \mathrm{s}^{-1}$ during the experiment and was generally from a southwest direction although it was from the northwest and west-northwest on two dates during the experiment (Table 1). Air temperature ranged from 21.2 to 
Table 2. 'Red Rome' apple tree measurements and spray volume discharged when spraying three growth stages in variablerate and constant-rate modes.

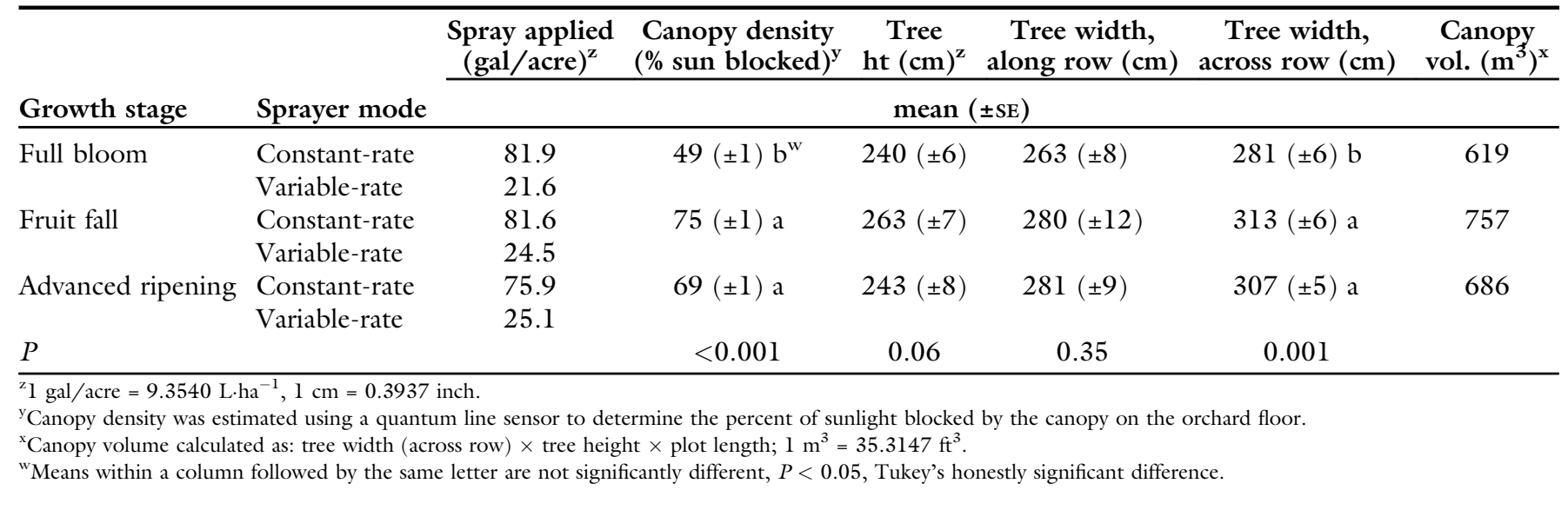

Table 3. 'Pinot noir' grape vine measurements and spray volume discharged when spraying three growth stages in variablerate and constant-rate modes.

\begin{tabular}{|c|c|c|c|c|c|c|}
\hline \multirow[b]{2}{*}{ Growth stage } & \multirow[b]{2}{*}{ Sprayer mode } & $\begin{array}{c}\text { Spray applied } \\
\text { (gal/acre) }^{\mathrm{z}}\end{array}$ & Canopy density $^{\mathrm{y}}$ & $\begin{array}{c}\text { Shoot length } \\
\text { (inches) }^{\mathrm{Z}}\end{array}$ & $\begin{array}{c}\text { Leaves (no./ } \\
\text { shoot) }\end{array}$ & $\begin{array}{c}\text { Canopy vol. } \\
\left(\mathrm{ft}^{3}\right)^{\mathrm{x}} \\
\end{array}$ \\
\hline & & \multicolumn{5}{|c|}{ mean $( \pm$ SE) } \\
\hline Prebloom & Variable-rate & $23( \pm 1) a$ & $0.35( \pm 0.02) \mathrm{a}$ & $25.8( \pm 2.0) \mathrm{a}$ & $9( \pm 0.4) \mathrm{a}$ & $61( \pm 14) a$ \\
\hline \multirow[t]{2}{*}{ Full bloom } & Constant-rate & $110( \pm 0.4) \mathrm{c}$ & $0.60( \pm 0.02) b$ & $54.6( \pm 1.2) \mathrm{b}$ & $14( \pm 0.1) b$ & $164( \pm 21) b$ \\
\hline & Variable-rate & $42( \pm 2) b$ & $0.61( \pm 0.01) b$ & $55.9( \pm 2.9) \mathrm{b}$ & $14( \pm 0.4) b$ & $171( \pm 22) b$ \\
\hline Full canopy & Variable-rate & $43( \pm 2) b$ & $0.64( \pm 0.01) \mathrm{b}$ & $54.3( \pm 1.4) \mathrm{b}$ & $14( \pm 0.8) b$ & $194( \pm 21) b$ \\
\hline$P$ value & & $<0.001$ & $<0.001$ & $<0.001$ & $<0.001$ & $<0.001$ \\
\hline
\end{tabular}

${ }^{\mathrm{z}} 1 \mathrm{gal} /$ acre $=9.3540 \mathrm{~L} \cdot \mathrm{ha}^{-1}, \mathrm{l}$ inch $=2.54 \mathrm{~cm}$.

${ }^{\mathrm{y}}$ Canopy density as measured with the light detection and ranging laser sensor. Values are a unitless proportion (e.g., cubic foot per cubic foot).

${ }^{\mathrm{x}}$ Canopy volume calculated as canopy width $\times$ canopy height $\times$ plot length; $1 \mathrm{ft}^{3}=0.0283 \mathrm{~m}^{3}$.

${ }^{\text {w }}$ Means within a column followed by the same letter are not significantly different, $P<0.05$, Tukey's honestly significant difference.

$29.5^{\circ} \mathrm{C}$ and humidity ranged from $29.0 \%$ to $56.9 \%$ during the experiment.

VINEYARD. Wind speed ranged from 1.1 to $3.0 \mathrm{~m} \cdot \mathrm{s}^{-1}$ in the vineyard and was from the east (Table 1). Air temperature and humidity ranged from 18.6 to $25.0{ }^{\circ} \mathrm{C}$ and $48.0 \%$ to $66.6 \%$, respectively.

\section{Spray volume}

Orchard. The application rate at full bloom, fruit fall, and advanced ripening was $81.9,81.6$, and 75.9 gal/acre in the constant-rate mode, respectively, and 21.6, 24.5, and 25.1 $\mathrm{gal} /$ acre in the variable-rate mode, respectively $[P=0.03$ (Table 2$)]$.

VINEYARD. The application rate at prebloom, full bloom, and full canopy was 111,110 , and $110 \mathrm{gal} /$ acre in the constant-rate mode, respectively, and 23,42 , and $43 \mathrm{gal} /$ acre in the variable-rate mode, respectively $[P<$ 0.05 (Table 3)].

\section{Spray coverage and deposit density}

OrChard. For coverage, there were main effects from the sprayer mode $(P<0.0001)$, the card positions $(P<0.0001)$, and the growth stage $(P<0.0001)$. There were also interactions between the sprayer mode $\times$ card position $\times$ growth stage $(P<0.0001)$, card position $\times$ growth stage $(P<0.0001)$, and sprayer mode $\times$ card position interaction $(P<$ $0.0001)$, but not the sprayer mode $\times$ growth stage $(P=0.5040)$. At each growth stage for all target card positions, WSC coverage was greater in the constant-rate mode (22\% to $97 \%$ ) compared with WSC coverage recorded during the variable-rate mode [6\% to $69 \%$ (Fig. 5)]. WSC coverage was also greater on the ground and aerial drift cards when the sprayer was operated in constant-rate mode $(6 \%$ to $74 \%$ ) compared with drift card coverage during the variable-rate mode ( $1 \%$ to $30 \%)$.
For deposit density (droplets per square centimeter), there were main effects of sprayer mode $(P<0.0001)$, card position $(P<0.0001)$, and growth stage $(P<0.0001)$, as well as interactions between sprayer mode $\times$ card position $\times$ growth stage $(P<$ $0.0001)$, card position $\times$ growth stage $(P<0.0001)$, sprayer mode $\times$ card position $(P<0.0001)$, and sprayer mode $\times$ growth stage $(P<$ $0.0001)$. For nearly all of the proximal and distal cards, the variable-rate sprayer had greater deposit densities ( 72 to 242 droplets $/ \mathrm{cm}^{2}$ ) than the deposit densities during constant-rate sprayer mode (2 to 217 droplets/ $\mathrm{cm}^{2}$ ) during full bloom and fruit fall (Fig. 5A and B). The one exception, where deposit density was greater during constant-rate mode, was a distal card (4P) collected during fruit fall (Fig. 5B). However, during the advanced ripening stage, the proximal cards $(1 \mathrm{P}, 2 \mathrm{P}, 3 \mathrm{~S}, 4 \mathrm{~S})$ sprayed in the variable-rate mode resulted in greater 


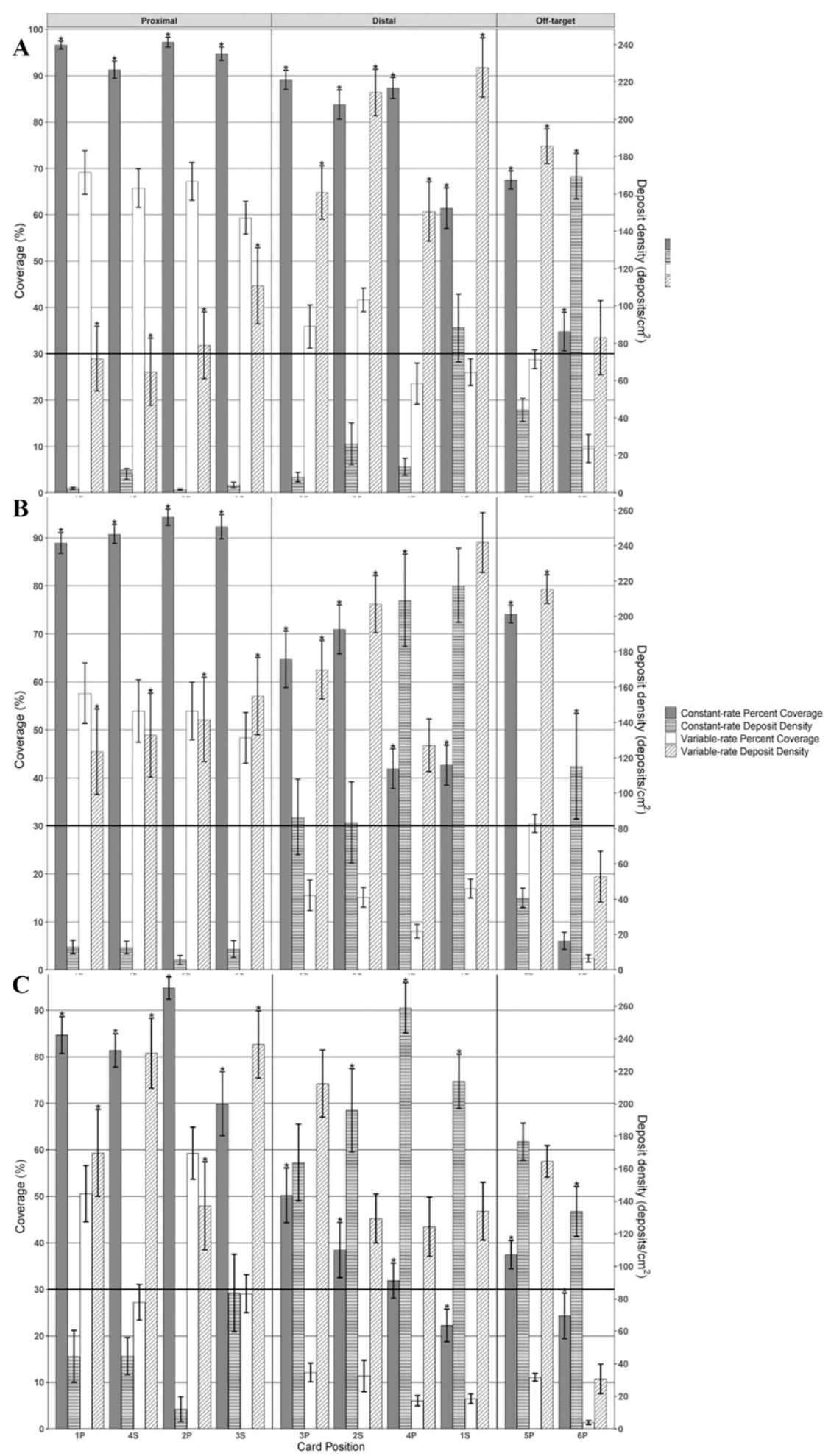

Fig. 5. Mean percent coverage and deposit density on water-sensitive cards (WSC) in 'Red Rome' apple trees sprayed at three growth stages [(A) full bloom, (B) fruit fall, $(\mathrm{C})$ advanced ripening] in variable-rate and constant-rate modes. Proximal WSC positions $1 P$ and $2 P$ face the primary driveway, proximal WSC positions $3 S$ and $4 S$ face the secondary driveway, distal WSC positions $1 S$ and $2 S$ face the secondary driveway, and distal WSC positions $3 \mathrm{P}$ and $4 \mathrm{P}$ face the primary driveway. WSC position 5P is the ground WSC, and WSC position 6P is the aerial drift card. Uncertainty intervals are standard error, the asterisk indicates a significant difference between variable-rate and constant-rate spray modes at that WSC position and growth stage. The horizontal bar denotes a $30 \%$ overspray threshold. deposits density than those sprayed in the constant-rate mode, whereas the distal cards sprayed in the constantrate mode had a deposit density that was either not different $(3 \mathrm{P})$ or greater $(1 S, 2 S, 4 \mathrm{P})$ than those sprayed in the variable-rate mode (Fig. $5 \mathrm{C}$ ). Unlike most of the other card positions, the deposit density on aerial drift cards (6P) was consistently less in the variable-rate mode than in the constantrate mode.

Vineyard. For coverage, the main effects of sprayer mode $(P=$ $0.0009)$ and card position $(P<$ $0.0001)$ were significant, but not growth stage $(P=0.0648)$. The interactions between sprayer mode $\times$ card position $(P=0.1125)$ and sprayer mode $\times$ card position $\times$ growth stage interaction $(P=0.4360)$ were not significant. Yet there was an interaction between card position $\times$ growth stage $(P<0.0001)$. At each growth stage, the spray coverage of WSC $(60 \%$ to $70 \%$ ) was greater in the cluster zone (positions $\mathrm{CE}$ and $\mathrm{CW}$ ) when the sprayer was operated in the constantrate spray mode, compared with coverage of WSC (25\% to $45 \%)$ when the sprayer was operated in the variablerate sprayer mode (Fig. 6). In both target leaf positions, the constant-rate sprayer mode resulted in greater mean WSC coverage $(\mathrm{AB} \quad 51 \%$ and $\mathrm{AD}$ $32 \%$ ) than the variable-rate spray mode ( $\mathrm{AB} 26 \%$ and $\mathrm{AD} 7 \%$ ) at prebloom. Mean WSC coverage between sprayer modes was not different between $\mathrm{AB}$ and $\mathrm{AD}$ at full-bloom or full-canopy growth stages (Fig. 6B and C). Drift coverage (position D) was greater in the constant-rate mode (46\%) compared with the variable-rate mode (13\%) at prebloom (Fig. 6A) .

For deposit density, the main effects of sprayer mode $(P=0.0049)$, card position $(P=0.0032)$, and growth stage $(P<0.0001)$ were all significant. There were also significant interactions between sprayer mode $\times$ card position $\times$ growth stage $(P=0.0106)$, card position $\times$ growth stage $(P<0.0001)$, and sprayer mode $\times$ card position $(P=$ $0.0003)$, but not sprayer mode $\times$ growth stage $(P=0.1330)$. Mean deposit densities collected from cards placed in the canopy sprayed by the variable-rate mode ranged from $\approx 70$ to 120 droplets $/ \mathrm{cm}^{2}$, whereas those for the constant-rate mode ranged from $\approx 20$ to 120 droplets $/ \mathrm{cm}^{2}$ (Fig. 


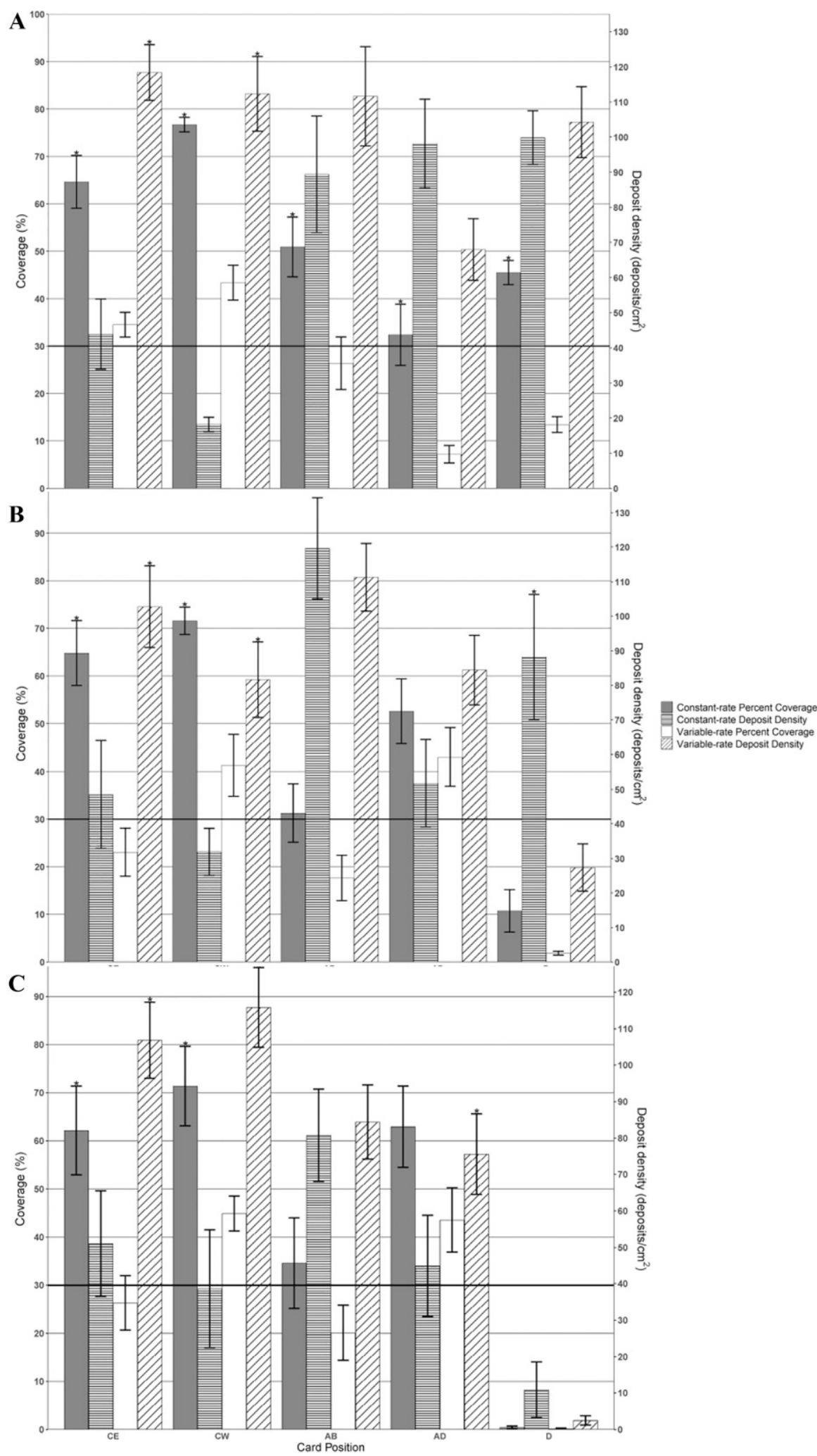

Fig. 6. Mean percent coverage and deposit density on water-sensitive cards (WSC) in 'Pinot noir' vines sprayed at three growth stages [(A) pre-bloom, (B) full bloom, $(C)$ full canopy] in variable-rate and constant-rate modes. The WSC positions are from left to right: cluster WSC facing east (CE), cluster WSC facing west, $(C W)$ abaxial leaf surface $(A B)$, adaxial leaf surface $(A D)$, and drift WSC (D). Uncertainty intervals are standard error, the asterisk indicates a significant difference between variable-rate and constant-rate spray modes at that WSC position and growth stage. The horizontal bar denotes a $\mathbf{3 0} \%$ overspray threshold.
6). On leaves in the canopy (positions $\mathrm{AD}$ and $\mathrm{AB}$ ), the only significant difference occurred on the upper leaf surface at full canopy with the variable-rate resulting in 76 droplets $/ \mathrm{cm}^{2}$ and the constant-rate mode resulting in 45 droplets $/ \mathrm{cm}^{2}$ (Fig. 6C). There was no difference in deposit density due to sprayer mode in the drift position at pre-bloom or full canopy (Fig. 6A and C); however, when the sprayer was operated in the constant-rate mode at full bloom, it resulted in greater deposit density than the variable-rate mode (Fig. 6B).

\section{Discussion}

The greatest differences in the volume of pesticide application between constant- and variable-rate sprayer modes occurred early in the season when the canopy was sparse (Figs. 3 and 4). At full bloom, the 'Red Rome' apple trees had little foliage and no shoot growth. At pre-bloom, the 'Pinot noir' grapevines had variable shoot growth with much of the trellis lacking vegetation. In the orchard, spray volume was reduced by $74 \%, 70 \%$, and $67 \%$ in the variable-rate mode compared with the constant-rate mode at full bloom, fruit fall, and advanced ripening, respectively (Table 2). In the vineyard, spray volume was reduced by $80 \%, 62 \%$, and $61 \%$ in the variable-rate mode compared with the constant-rate mode at pre-bloom, full bloom, and full canopy, respectively (Table 3 ). Reduced spray volumes by the variable-rate sprayer mode support previous research in which variable-rate spraying also greatly reduced the volume of pesticide applied in orchards (Fessler et al., 2020), vineyards (Llorens et al., 2010), and tree nursery production systems (Zhu et al., 2017). Previous studies positively correlated spray volume with spray coverage up to the point of leaf saturation (Miranda-Fuentes et al., 2015; Wise et al., 2010).

Spray coverage was typically greater in the constant-rate mode compared with using the variable-rate mode. In the orchard, all cards across all three growth stages had greater coverage when sprayed in the constant-rate spray mode (Fig. 5). In the vineyard, during the full-bloom and full-canopy phenophases, the constant-rate mode applied more than two and a half times the volume of the variable-rate mode (Table 3 ). However, coverage was only greater 
in the cluster zone (Fig. 6). This interaction of coverage and spray card position may be explained by the intelligent sprayer technology. The control system triggers each nozzle to apply the calculated amount of spray volume based on its target's characteristics (Chen et al., 2012) and underscores how the sensing technology can eliminate overapplication of pesticides, which is typical of conventional air-blast sprayers. Conventional sprayers are normally operated to sufficiently cover the densest foliage. During the full-bloom and fullcanopy phenophases, leaves were the densest part of the grapevine and where the laser would have signaled the computer to apply more pesticides than other areas. There were no differences in coverage between the constant-rate and the variable-rate spray modes when the vines were their densest because the constant-spray was not excessive in these locations at these stages. Howev$\mathrm{er}$, in the grape cluster zone where foliage density naturally remains low throughout the season, the intelligent technology recognized the lighter density and reduced pesticide output accordingly. The sensing technology reduced coverage in the cluster zone in the vineyard and all canopy positions in the orchard throughout the season. These results suggest that apple orchard foliage density was never as dense as the constant-rate spray mode was designed to cover. Excessive spray has previously been attributed to the fact that constant-rate spray systems were designed for historical orchard systems in which the trees were much larger and denser (Warneke et al., 2020). Greater spray volumes can decrease application efficiency, spray penetration, droplet uniformity, and create runoff that is transferred to the ground (Miranda-Fuentes et al., 2015).

The constant-rate spray mode discharged a constant volume regardless of the canopy characteristics causing pesticide spray to drift through the open canopies beyond the desired target. In both production systems, the variable-rate spray mode reduced pesticide drift from the first spray application, which was during full bloom for the 'Red Rome' apple trees and prebloom for the 'Pinot noir' grapevines. Drift is a concern for adjacent areas considering that nontarget deposition has been detectable up to $100 \mathrm{ft}$ in orchards and vineyards when applied with air-blast sprayers (Grella et al., 2017). Reducing nontarget deposition is critical because aerial drift, ground spray, and runoff can contaminate surface and groundwater and have toxic effects on nontarget species (Grella et al., 2017; Kasner et al., 2020; Pimentel and Burgess, 2012; Toccalino et al., 2014). Spray applications to sparse canopies increase drift and nontarget ground deposition, which can lead to deleterious human and environmental health effects (Kasner et al., 2018; Kim et al., 2017) and economic waste in terms of pesticide costs (Chen et al., 2013b; Manandhar et al., 2020). Although drift can be decreased through best management practices including using a well-maintained sprayer and calibrating to match the crop canopy volume (Gil and Escolà, 2009; Rüegg and Viret, 1999), many operators neglect to perform these tasks. Even when replicated tree measurements are carefully made, constant-rate applications based on tree row volume can still apply 6-fold more pesticide than variable-rate technology without an improvement in spray application characteristics (Fessler et al., 2020). Unlike the constant-rate spray mode, the machine-vision variable-rate sprayer mode made real-time adjustments, decreasing the application volume when vegetation was absent (Tables 2 and 3 ), which resulted in a more targeted spray and decreased drift and off-target ground spray (Figs. 5 and 6). Increasing spray efficiency is critically important because spray losses to the ground and aerial drift by constant-rate, air-assist sprayers can be $40 \%$ to $60 \%$ of total applied spray in orchards (Cross et al., 200la, 2001b; Holownicki et al., 2000 ), and $10 \%$ to $50 \%$ the total applied spray volume in vineyards (Pergher et al., 1997). The results from the present study demonstrate that air-assisted sprayers retrofitted with a laser-guided computer-controlled variable-rate spray mode can be considered drift reduction technologies (DRT) according to the U.S. Environmental Protection Agency (USEPA) guidelines. This is an important finding because air-assisted sprayers need scientific verification for inclusion in the USEPA DRT program, which specifically aims to "expand ... to include technologies for orchard and vineyard crops" (USEPA, 2020).

Excessive spray applications can also confound the accuracy of spray quality metrics, especially deposit density. Deposit density is a measure of the number of droplets per square centimeter of WSC area. When the number of droplets on a leaf increases, at some point the drops coalesce and overlapping droplets appear as a single large droplet causing the deposit density to be artificially low. This situation was demonstrated in results from the orchard where all four proximal cards (1P, 2P, 3S, and 4S) had very high coverage $(>75 \%)$ in the constant-rate mode at full bloom and fruit fall (Fig. $5 \mathrm{~A}$ and $\mathrm{B}$ ). These cards were heavily coated by sprays with many overlapping deposits, which was recorded by DepositScan as very low deposit densities $\left(<20\right.$ droplets $\left./ \mathrm{cm}^{2}\right)$. Therefore, the 10 times smaller deposit density in constant-rate mode than in the variable-rate mode at full bloom and fruit fall was an artifact of the saturating coverage. Previously, Chen et al. (2013a) established an overspray (i.e., excessive spray) index by normalizing spray coverage with the following equation: $I_{O}=\frac{C-30}{100-30}$ where $I_{O}$ is the overspray index and $C$ is the spray coverage (percent) on WSC. By applying this standard, the constant-rate spray mode created overspray conditions (i.e., $>30 \%$ coverage) at both the orchard and the vineyard at all growth stages and all proximal target spray card positions. Moreover, coverage exceeded $50 \%$ when using the constantrate mode on all proximal cards at all growth stages in the orchard (Fig. 5). In the vineyard, the constant-rate applications to the cluster zone and half of the leaf zones also exceeded 50\% coverage at all growth stages; however, in the variable-rate mode spray coverage was closer to $30 \%$ (Fig. 6). Although the variable-rate mode resulted in lower coverage in the orchard, the WSC data reveal that even in this mode that most proximal cards were oversprayed at full-bloom and fruit fall stages. WSC may behave differently than plant leaves. Generally, WSC are more rigid than leaves and therefore may respond differently to blasts of air generated by the sprayers. Additionally, different spray formulations (e.g., surfactants) and leaf canopies may affect the physical interaction of the spray liquid with the leaf surface. This study used a high number of WSC replications and repeated sampling, which has been shown as a valid method to 
effectively detect spray trends (Salyani et al., 2013).

It is difficult to generalize the interaction between spray coverage and deposit density on pest management because within each pesticide class there is a wide degree of variability in the chemical activity of individual active ingredients and pesticide formulations (Gossen et al., 2008). For instance, contact-type pesticides are only active on target organisms that touch pesticide deposits, unlike systemic pesticides that translocate through plant tissue. When a contact pesticide is used, spray coverage may be a better metric than deposit density because even with a high density of droplets, some leaf area remains untreated upon which an arthropod could land and cause damage or a spore from a pathogen may invade the plant tissue. The inverse response could be true for a systemic pesticide that could redistribute through a plant, where a large number of evenly spaced droplets per square centimeter would be ideal to allow the pesticide to evenly diffuse through the plant. Variable-rate sprayers have effectively controlled arthropods and diseases in limited other studies (Chen et al., 2019, 2020). Recent research using variable-rate pesticide application technology on established, dense 'Golden Delicious' apple trees suggests that even a rate as low as $0.03 \mathrm{fl} \mathrm{oz} / \mathrm{ft}^{3}$, which is less than half of the intelligent sprayer's default rate used in this study, supplies sufficient deposit density (Fessler et al., 2020). Collectively, these findings highlight the need to reexamine the dose responses of pesticides applied with greater precision in orchard systems and the potential for large reductions in pesticide volume simply by lowering the per acre rate applied by conventional sprayers.

The results of this study demonstrate how variable-rate spray systems are more efficient than constant-rate spraying, especially when canopies are sparse. If disease and arthropod control are not diminished, reducing the pesticide volume applied on a farm has multifaceted benefits. The most direct benefit, and usually the one that motivates the adoption of variable-rate systems, comes from a reduction in pesticide costs due to lower application volumes. Manandhar et al. (2020) found variable-rate technology can reduce pesticide costs by as much as
$67 \%$. Reducing the amount of active ingredient per application also causes a concomitant decrease in environmental impact and worker exposure. Moreover, when the quantity of pesticide required to treat an area is decreased, additional efficiencies are realized from the reduced need to refill, such as lower fuel and labor costs, and improved ability to complete applications in windows of good weather. Additionally, requiring less water as in the case of lower spray volumes is beneficial for orchards and vineyards that have limited access to water. Research opportunities for variable-rate spray systems include different production systems, demonstrating interactions between coverage and efficacy, and expanded inquiry into how plant phenological stages affect spray quality metrics.

\section{Literature cited}

Austin, C.N., G.G. Grove, J.M. Meyers, and W.F. Wilcox. 2011. Powdery mildew severity as a function of canopy density: Associated impacts on sunlight penetration and spray coverage. Amer. J. Enol. Viticult. 62(1):23-31, doi: 10.5344/ajev. 2010.10077 .

Bechtel, L., B.H. Barritt, M.A. Dilley, and H.R. Hinman. 1995. Economic analysis of apple orchard management systems with three varieties in central Washington. Washington State Univ. Res. Bul. XB1032: $1-48$.

Chen, L., M. Wallhead, M. Reding, L. Horst, and H. Zhu. 2020. Control of insect pests and diseases in an Ohio fruit farm with a laser-guided intelligent sprayer. HortTechnology 30(2):168-175, doi: 10.21273/HORTTECH04497-19.

Chen, L., M. Wallhead, H. Zhu, and A. Fulcher. 2019. Control of insects and diseases with intelligent variable-rate sprayers in ornamental nurseries. J. Environ. Hort. 37(3):90-100, doi: 10.24266/0738-28 98-37.3.90.

Chen, Y., H.E. Ozkan, H. Zhu, R.C. Derksen, and C.R. Krause. 2013a. Spray deposition inside tree canopies from a newly developed variable-rate air-assisted sprayer. Trans. ASABE 56(6):1263-1272, doi: $10.13031 /$ trans.56.9839.

Chen, Y., H. Zhu, and H. Ozkan. 2012. Development of a variable-rate sprayer with laser scanning sensor to synchronize spray outputs to tree structures. Trans. ASABE 55(3):773-781, doi: 10.13031/ 2013.41509

Chen, Y., H. Zhu, H.E. Ozkan, R.C. Derksen, and C.R. Krause. 2013b. Spray drift and off-target loss reductions with a precision air-assisted sprayer. Trans. ASABE 56(6):1273-1281, doi: 10.13031/trans. 56.10173 .

Cross, J., P. Walklate, R. Murray, and G. Richardson. 200la. Spray deposits and losses in different sized apple trees from an axial fan orchard sprayer: 1. Effects of spray liquid flow rate. Crop Prot. 20(1): 13-30, doi: 10.1016/S0261-2194(00) 00046-6.

Cross, J., P. Walklate, R. Murray, and G. Richardson. 2001b. Spray deposits and losses in different sized apple trees from an axial fan orchard sprayer: 2. Effects of spray quality. Crop Prot. 20(4):333-343, doi: 10.1016/S0261-2194(00)00163-0.

da Silva Scapin, M., F. Behlau, L.H.M. Scandelai, R.S. Fernandes, G.J.S. Junior, and H.H. Ramos. 2015. Tree-row-volume-based sprays of copper bactericide for control of citrus canker. Crop Prot. 77:119-126, doi: 10.1016/j.cropro.2015. 07.007 .

Fessler, L., A. Fulcher, D. Lockwood, W. Wright, and H. Zhu. 2020. Advancing sustainability in tree crop pest management: Refining spray application rate with a laser-guided variable-rate sprayer in apple orchards. HortScience 55(9):1522-1530, doi: 10.21273/HORTSCI15056-20.

Fox, R.D., R.C. Derksen, H. Zhu, R.D. Brazee, and S.A. Svensson. 2008. A history of air-blast sprayer development and future prospects. Trans. ASABE 51(2):405-410, doi: $10.13031 / 2013.24375$.

Gil, E. and A. Escolà. 2009. Design of a decision support method to determine volume rate for vineyard spraying. Appl. Eng. Agr. 25(2):145-151, doi: 10.13031/ 2013.26323 .

Giles, D., P. Klassen, F. Niederholzer, and D. Downey. 2011. "Smart" sprayer technology provides environmental and economic benefits in California orchards. Calif. Agr. 65(2):85-89, doi: 10.3733/ca. v065n02p85.

Gossen, B.D., G. Peng, T.M. Wolf, and M.R. McDonald. 2008. Improving spray retention to enhance the efficacy of foliarapplied disease-and pest-management products in field and row crops. Can. J. Plant Pathol. 30(4):505-516, doi: 10.1080/ 07060660809507550 .

Grella, M., M. Gallart, P. Marucco, P. Balsari, and E. Gil. 2017. Ground deposition and airborne spray drift assessment in vineyard and orchard: The influence of environmental variables and sprayer settings. Sustainability 9(5):728, doi: 10.3390/ su9050728.

Grella, M., P. Marucco, and P. Balsari. 2019. Toward a new method to classify 
the airblast sprayers according to their potential drift reduction: Comparison of direct and new indirect measurement methods. Pest Manag. Sci. 75(8):2219-2235, doi: 10.1002/ps.5354.

Holownicki, R., G. Doruchowski, A. Godyn, and W. Swiechowski. 2000. Effects of air jet adjustment on spray losses in orchard. Asp. Appl. Biol. (57):293-300.

Kasner, E.J., R.A. Fenske, G.A. Hoheisel, K. Galvin, M.N. Blanco, E.Y. Seto, and M.G. Yost. 2018. Spray drift from a conventional axial fan airblast sprayer in a modern orchard work environment. Ann. Work Expo. Health 62(9):1134-1146, doi: 10.1093 /annweh/wxy082.

Kasner, E.J., R.A. Fenske, G.A. Hoheisel, K. Galvin, M.N. Blanco, E.Y. Seto, and M.G. Yost. 2020. Spray drift from three airblast sprayer technologies in a modern orchard work environment. Ann. Work Expo. Health 64(1):25-37, doi: 10.1093/ annweh/wxz080.

Kim, K.-H., E. Kabir, and S.A. Jahan. 2017. Exposure to pesticides and the associated human health effects. Sci. Total Environ. 575:525-535, doi: 10.1016/ j.scitotenv.2016.09.009.

Liu, H. and H. Zhu. 2016. Evaluation of a laser scanning sensor in detection of complex-shaped targets for variable-rate sprayer development. Trans. ASABE 59(5):11811192, doi: 10.13031/trans.59.11760.

Llorens, J., E. Gil, J. Llop, and A. Escolà. 2010. Variable rate dosing in precision viticulture: Use of electronic devices to improve application efficiency. Crop Prot. 29(3):239-248, doi: 10.1016/j.cropro. 2009.12.022.

Manandhar, A., H. Zhu, E. Ozkan, and A. Shah. 2020. Techno-economic impacts of using a laser-guided variablerate spraying system to retrofit conventional constant-rate sprayers. Precis.
Agr. 21:1156-1171, doi: 10.1007/ s11119-020-09712-8.

Meier, U. 2018. Growth stages of monoand dicotyledonous plants. BBCH Monogr. Julius Kühn-Institut, Quedlinburg, Germany, doi: 10.5073/20180906-074619.

Miranda-Fuentes, A., A. Rodríguez-Lizana, E. Gil, J. Agüera-Vega, and J.A. Gil-Ribes. 2015. Influence of liquid-volume and airflow rates on spray application quality and homogeneity in super-intensive olive tree canopies. Sci. Total Environ. 537:250-259, doi: 10.1016/j.scitotenv.2015.08.012.

Pergher, G., R. Gubiani, and G. Tonetto. 1997. Foliar deposition and pesticide losses from three air-assisted sprayers in a hedgerow vineyard. Crop Prot. 16(1):25-33, doi: 10.1016/S0261-2194(96)00054-3.

Pimentel, D. and M. Burgess. 2012. Small amounts of pesticides reaching target insects. Environ. Dev. Sustain. 14:1-2, doi: 10.1007/s10668-011-9325-5.

Rüegg, J. and O. Viret. 1999. Determination of the tree row volume in stone-fruit orchards as a tool for adapting the spray dosage. European Mediterranean Plant Protection Organization Bul. 29:95-101, doi: 10.1111/j.1365-2338.1999.tb00802.x.

Salyani, M., H. Zhu, R. Sweeb, and N. Pai. 2013. Assessment of spray distribution with water-sensitive paper. Agr. Eng. Intl. Commission Internationale Génie Rural J. 15(2):101-111.

Sambucci, O., J.M. Alston, and K.B. Fuller. 2014. The costs of powdery mildew management in grapes and the value of resistant varieties: Evidence from California. Robert Mondavi Inst. Ctr. Wine Econ. Publ. Working Paper 1402.

Thiessen, L., T. Neill, and W. Mahaffee. 2017. Timing fungicide application intervals based on airborne erysiphe necator concentrations. Plant Dis. 101(7):1246-1252, doi: 10.1094/PDIS-12-16-1727-RE.
Toccalino, P.L., R.J. Gilliom, B.D. Lindsey, and M.G. Rupert. 2014. Pesticides in groundwater of the United States: Decadal-scale changes, 1993-2011. Ground Water 52(S1):112-125, doi: 10.1111/gwat. 12176.

Tona, E., A. Calcante, and R. Oberti. 2018. The profitability of precision spraying on specialty crops: A technical-economic analysis of protection equipment at increasing technological levels. Precis. Agr. 19:606-629, doi: 10.1007/s11119-0179543-4.

U.S. Environmental Protection Agency. 2020. About the drift reduction technology program. 10 Nov. 2020. <https://www.epa.gov/reducing-pesticide-drift/aboutdrift-reduction-technology-program $>$.

Warneke, B.W., H. Zhu, J.W. Pscheidt, and L.L. Nackley. 2020. Canopy spray application technology in specialty crops: A slowly evolving landscape. Pest Manag. Sci. 77(3):1-8, doi: 10.1002/ ps.6167.

Wise, J.C., P.E. Jenkins, A.M. Schilder, C. Vandervoort, and R. Isaacs. 2010. Sprayer type and water volume influence pesticide deposition and control of insect pests and diseases in juice grapes. Crop Prot. 29(4):378-385, doi: 10.1016/ j.cropro.2009.11.014.

Zhu, H., R. Rosetta, M.E. Reding, R.H. Zondag, C.M. Ranger, L. Canas, A. Fulcher, R.C. Derksen, H.E. Ozkan, and C.R. Krause. 2017. Validation of a laserguided variable-rate sprayer for managing insects in ornamental nurseries. Trans. ASABE 60(2):337-345, doi: 10.13031/ trans. 12020 .

Zhu, H., M. Salyani, and R.D. Fox. 2011. A portable scanning system for evaluation of spray deposit distribution. Comput. Electron. Agr. 76(1):38-43, doi: 10.1016/ j.compag.2011.01.003. 